УДК 378.091.398:61

\title{
СТУДЕНТСЬКИЙ НАУКОВИЙ ГУРТОК ЯК ШЛЯХ ПІДВИЩЕННЯ РІВНЯ ЗНАНЬ ЗА КРЕДИТНО-МОДУЛЬНОЮ СИСТЕМОЮ
}

\author{
Б. І. Шумко, В. В. Шульгіна, Л. Я. Федонюк* \\ Буковинський державний медичний університет, м. Чернівці, \\ "ДВНЗ “Тернопільський держсавний медичний університет імені І. Я. Горбачевського \\ МОЗ України”
}

\section{STUDENTS SCIENTIFIC SOCIETY AS A WAY TO IMROVE THE LEVEL OF KNOWLEDGE ACCORDING TO THE ECTS}

\author{
B. I. Shumko, V. V. Shulhina, L. Ya. Fedonyuk* \\ Bukovynian State Medical University, Chernivtsi, \\ *SHEI “Ternopil State Medical University by I. Ya. Horbachevsky of MPH of Ukraine”
}

\begin{abstract}
Навчальний процес за Болонською системою навчання зумовлює необхідність пошуку викладачами нових або вдосконалення наявних методів навчання студентів для формування висококваліфікованого та конкурентоспроможного фахівця.
\end{abstract}

Academic process according to the Bologna Process determines the necessity to look for new methods of teaching or improvement of the existing ones by the faculty to form highly qualified and competitive specialists.

Вступ. Активні трансформаційні процеси, які на сучасному етапі переживає національна система вищої освіти' є передумовами входження України до єдиної Європейської зони вищої освіти. Реалізація вищою школою України ідей Болонського процесу має на меті підготовку конкурентоспроможних фахівців. У свою чергу, це вимагає від педагогічних колективів вітчизняних закладів освіти обов'язкового ознайомлення студентів 3 прийомами аналітично-пошукової роботи, селекції інформації та публічного виступу. На сучасному етапі одним із пріоритетних завдань держави $є$ підтримка й розвиток “молодої” науки.

Основна частина. Запровадження Болонської системи освіти зумовило зсув акценту на усне опитування, рішення тестових завдань і ситуаційних задач та самостійну роботу студента, які безперечно мають велике значення, в навчальному процесі, проте певною мірою обмежують час на вдосконалення практичних навичок у студентів та роботу із хворими. Одним із допоміжних методів поглиблення знань з дисципліни та вдосконалення практичних навичок $\epsilon$ студентський науковий гурток, де студент отримує основи науково-дослідної роботи, самостійно розвиває клінічне мислення, формує власну думку та професійні вміння.

Організація студентської наукової роботи стала одним з провідних напрямків діяльності кафедри он- кології та радіології і об’єктом посиленої уваги з боку завідувача кафедри, оскільки вона розширює світогляд, допомагає розвивати у студентів самостійність, пошуковість, творчість, ораторські здібності, вимогливість до себе та точність у роботі. Колективом кафедри було визначено основні принципи роботи гуртка, а саме: особиста зацікавленість викладачів, добровільність участі студентів, тісний зв'язок програми роботи гуртка з робочою навчальною програмою дисципліни “Онкологія”, регулярність роботи гуртка. Засідання гуртка проводиться двічі на місяць різними викладачами. Викладачі, як правило, вибирають тему, за якою вони працювали при написанні кандидатської чи докторської дисертації. Це дозволяє навчити гуртківців не лише теоретично-нового за даною тематикою, але передати практичні моменти, які зроблять студентів гідними наступниками своїх вчителів.

У студентському науковому гуртку займаються від 10 до 15 студентів 5 курсу. Студенти-гуртківці обирають головуючого, який веде засідання, й секретаря для ведення протоколу з ретельною фіксацією хворих і студентів, які про них доповідали. На кожному засіданні гуртка студенти беруть активну участь у вечірніх лікарських обходах, проводять курацію тематичного хворого, заслуховують доповіді наукового або реферативного характеру (співвідношення

() Б. І. Шумко, В. В. Шульгіна, Л. Я. Федонюк 
таких доповідей 1:1), переглядають навчальні відеофільми. У реферативних повідомленнях подається огляд матеріалів, викладених у профільних журналах і монографіях. Студенти нерідко стають активними помічниками в науковій роботі співробітників кафедри. Опублікована стаття має неабияке значення й значною мірою впливає на подальшу долю студента. Нерідко розпочаті в студентському науковому гуртку дослідження плавно переростають у фрагмент дисертаційної роботи. Заняття в гуртку значно полегшують входження майбутнього лікаря до лікарського колективу після закінчення вишу. При цьому студенти-гуртківці не забувають про своє основне завдання - вчитися. При плануванні тематики засідань і наукових досліджень особливий акцент робиться на сучасних скринінгових методах ранньої діагностики онкологічних захворювань, стандартах онкологічної допомоги.

На підставі виконаних досліджень провадиться підготовка матеріалів до публікації в студентському збірнику наукових праць, а також цілеспрямована робота 3 підготовки студентів-гуртківців до виступів

\section{Література}

1. Вища освіта України і Болонський процесс : навчальний посібник / за ред. В. Г. Кременя. - Тернопіль : Навчальна книга-Богдан, 2004. -384 c.

2. Мороз І. В. Педагогічні умови запровадження кредит- на підсумкових щорічних університетських наукових конференціях на секції “Онкологія”. Авторів кращих наукових робіт заохочують подарунками.

Багаторічний досвід свідчить, що студентигуртківці володіють кращими теоретичними знаннями та практичними навичками в онкології і враховуючи потреби практичної медицини після закінчення вузу, працюючи практичними лікарями краще орієнтуються у загальних питаннях онкології.

Висновок. Існування студентського наукового гуртка $є$ необхідним для становлення і розвитку майбутнього фахівця. Тут майбутні лікарі знаходять задоволення своїх потреб: хтось удосконалює і поглиблює свої знання, хтось знаходить свою наукову стежину, хтось прагне отримати свої додаткові бали поточної успішності.

Студенти-гуртківці переймають досвід своїх старших колег та наставників, які із задоволенням передають набуті за довгі роки своєї професійної діяльності знання юним колегам для того, щоб у майбутньому останні стали висококваліфікованими фахівцями.

но-модульної системи організації навчального процессу : монографія / І. В. Мороз. -К. : ТОВ “Освіта України”, 2005. $-278 \mathrm{c}$. 